\title{
Climate Finance by Multinational Development Banks - with Special Attention to Europe
}

\author{
By Mária Bábosik*
}

The paper aims at highlighting the importance of climate protection in the world and in Europe due to climate change, as well as the role of multilateral development banks in climate finance. The topic has a current relevance as in 2017 President Donald Trump gave a notice to quit the Paris Climate Agreement accepted by all United Nations (UN) member states, amongst them by the members of the European Union (EU). The move of the United States (US) President was a shocking surprise worldwide and provoked heavy reactions - including the US. The paper gives an overview of the relationship between climate change, climate protection and climate finance. It sees climate change a threatening reality of today, affecting Europe as well. It considers climate protection necessary not only on country but also on regional and global level. Besides regulation and voluntary pledges, it attributes a crucial role to climate finance focusing on huge, long-term, high risk investments and projects to mitigate the effects and adapt to climate change. It mentions its sources, major directions and institutions, amongst them the multilateral development banks. It compares them with special attention to Europe exploring similarities and differences how climate finance is reflected in their policy, what resources they mobilize, what kind of projects they finance, what results they have achieved, what their plans are in this area and what reactions their activity provoke. Results show that multilateral development banks play a key role in climate finance. Due to differences in geographic, historic and economic circumstances and exposure to climate change they act on it differently. The paper helps to better understand the links between climate change, climate protection and climate finance and the role of the multilateral development banks in it in a comparative perspective.

Keywords: Climate Change, Climate Finance, Climate Protection, International Financial Institutions, Multilateral Development Banks.

\section{Introduction}

The purpose of the paper is to present the context of climate change, climate protection and climate finance, and to address the role played by Multilateral Development Banks (MDBs) in it. The topic is highly relevant as on June 1, 2017 US President Donald Trump gave a notice to quit the Paris Climate Agreement accepted by UN member states. In this epoch-making agreement, UN member states have committed themselves to limiting global warming to below 2 degrees Celsius by reducing emission of carbon dioxide. President Trump's decision sparked protests throughout the US and brought to life the "America's Pledge" initiative, to voluntarily comply with the Agreement and organize extensive campaigns to win the widest possible support. The US attitude is very important

"Senior Research Analyst, Central Bank of Hungary and PhD Student, University of Pécs, Hungary. 
not only because of the $\mathrm{CO} 2$ emission - as root cause of climate change - by the US itself, but the strong US influence on the international order and institutions.

The paper aims at finding answers to the following research questions: Can climate change be considered as a fact of today? Why has it become one of the key risk factors? Why is climate protection so important? What were the major steps made globally to protect the climate? How much investments are needed for climate protection? Who can provide them and in what form? What is the contribution of the Multilateral Development Banks to climate finance? What results have they achieved in this area and what could be improved? What kind of new questions did arise?

\section{Literature Review}

For this paper literature is reviewed in three different topics: climate change, climate finance and multilateral development banks. Each topic has many relevant publications, so without completeness only some of the most important literature is highlighted here.

Regarding climate change Andrew E. Dessler's (2012) book with the title of "Modern Climate Change" gives a very broad introduction defining climate change, explaining why it happens and what its effects are, and setting the fundamentals of the climate policy and actions. "Climate Change Denial: Heads in the Sand" by Haydn Washington and John Cook (2011) presents the standpoint of those who deny climate change with various arguments, reveals the interest behind them and uses scientific evidence to disprove them to realistically address the issue of climate change. Looking into the future Abishur Prakash (2016) in his book "Next Geopolitics" examines how new technologies will change geopolitics, amongst others the fight against climate change.

As for financing "Climate Finance: Theory and Practice" edited by Anil Markandya et al. (2017) gives a very good overview of the subject presenting the importance and debates on climate finance, providing theoretical and practical perspective to it and describing appraisal methods of investments. Regulatory and governance issues as well as market mechanisms are discussed in great details in the book "Climate Finance: Regulatory and Funding Strategies for Climate Change and Global Development" edited by Richard B. Stewart, Benedict Kingsbury and Bryce Rudyk (2009). A broad policy and regulatory overview and an empirical analysis on how financial institutions tackle climate change are given by Megan Bowman (2015) in "Banking on Climate Change". With regard to possible necessary actions, the book by Graeme Maxton and Jorgen Randers (2016) "Reinventing Prosperity" elaborates feasible proposals to reduce unemployment, inequality and climate change.

As far as Multilateral Development Banks are concerned, the role of Washington politics in the creation of these international financial institutions is revealed in the book by Sarah Babb (2009) titled "Behind the Development Banks". "Owning Development" edited by Susan Park and Antje Vetterlein (2010) presents how policy norms emerged and how they have changed in the IMF and 
the World Bank. Four regional development banks (RDBs) are thoroughly analyzed and compared by Ruth Ben-Artzi (2016) in her book on "Regional Development Banks in Comparison". She concludes that RDBs play a vital role in poverty elimination in spite of their institutional limitations. Robert O'Brien, Anne Marie Goetz, Jan Aart Scholte and Marc Williams (2000) in their book with the title of "Contesting Global Governance" focus on the critics against the policies and activities of the MDBs and show how global social movement can influence multilateral economic institutions.

This list of reviewed publications represents only a fragment of the very rich literature on the subject and could easily be enlarged. However, the role of the climate issue and the influence of international financial institutions through climate financing on geopolitics is not well presented.

\section{Methodology}

Methodology used in this paper is literature review, statistical analysis, and documents analysis regarding international negotiations on climate change and the publications of the Multilateral Development Banks as well as using relevant conference materials. Notre Dame Country Index of the University of Notre Dame (France) is also included to measure vulnerability and readiness of countries against climate change. $\mathrm{CO} 2$ emission data is drawn from EDGAR's database.

\section{Findings}

\section{From Climate Change to Climate Finance}

\section{The Challenge of Climate Change}

"Climate change" means a change of climate which is attributed directly or indirectly to human activity that alters the composition of the global atmosphere and which is in addition to natural climate variability observed over comparable time periods; as defined by the United Nations (UN 1992). Others associate climate change directly with global warming: "Climate change is the catch-all term for the shift in worldwide weather phenomena associated with an increase in global average temperatures". Wired (2018) widely used dictionaries underline the role of emission in defining climate change: "Changes in the world's weather, in particular the fact that it is believed to be getting warmer as a result of human activity increasing the level of carbon dioxide in the atmosphere." (Cambridge Dictionary n.d.) In my country a Hungarian curriculum quotes: "Climate change means the long-term and essential change of the Earth's climate and weather on local or global level. For example, changes in the temperature, the quantity and distribution of the rainwater, wind or the number of sunshine hours". (Tankönyvtár 2010) What explains climate change? Are there different opinions? What is the trend in climate change? 
Due to well-known explanations climate change is a consequence of the emission of greenhouse gases, mainly carbon dioxide (CO2), which is considered as the main reason of the increase in the average temperature of the Earth. Global warming may be fatal not only for the environment, but for the human civilization as well. Consequences can already be observed including melting ice cover and glaciers, higher sea level, slower ocean conveyor belt, altered flora, accelerated biodiversity loss, draught and heavy rainfalls, higher humidity, extreme weather events, etc. Unless we manage to limit the increase in temperature to less than 3.5 Celsius we will not survive, because food supply will be destroyed.

Not everybody is of this opinion. There is a wide range of climate sceptics, who have a different standpoint. "Trend sceptics" deny the fact of global warming and argue that climate changed even before. Others accept climate change as a fact but see nature being the cause of it. In contrast to them "Effect sceptics" see human activities as a cause but consider it being positive or neutral. Some are against regulation because of political-ideological considerations. "Science sceptics" question the validity of scientific research on climate change and argue that the models of the UN Intergovernmental Panel on Climate Change (IPCC) are not scientifically well grounded. They consider $\mathrm{CO} 2$ emission being only one of the factors influencing climate, and they oppose investing in emission reduction (Washington and Cook 2011).

One of the most well-known climate sceptics is Bjorn Lomborg, who assessed the actual impact of all climate promises made ahead of the Paris Climate Summit in 2015 and published shocking results. He concluded that even if every nation fulfilled every promise by 2030, and we assume that these promises could be extended for another 70 years until the end of this century, the Paris promises would reduce temperature rises by just 0.17 Celsius by 2100 . But this would cost us some USD 2-3 trillion over the next 25 years (Lomborg 2015).

Climate sceptics - though they are in minority and criticise the standpoint of the climate savers - are supported by lobbies and put considerable pressure on the public opinion as well as on the decision makers, well demonstrated by the attitude of the US President.

Nevertheless, during the past decade climate-related risks have increased tremendously. The World Economic Forum (WEF) assessed failure of climate change mitigation and adaptation the most important global risk factor (WEF 2016). Two years later the WEF stated, that "This trend has continued this year, with all five risks in the environmental category being ranked higher than average for both likelihood and impact over a 10-year horizon" (WEF 2018). The five risks mentioned above are as follows: Extreme weather events, Natural disasters, Failure of climate change mitigation and adaptation, Man-made environmental disasters, Biodiversity loss and ecosystem collapse.

\section{Vulnerability and Readiness to React on Climate Change}

Global warming affects the Earth everywhere but to a different extent. Due to different natural and social conditions some countries are more vulnerable to climate change impacts than others, and some countries are more prepared to cope 
with the challenge of climate change than the rest. Where are the hot spots, and which are the countries that are least ready to withstand the pressure of climate change? And where are the strongholds, countries that are least vulnerable and most ready to adapt? Which countries could improve their situation and which countries failed to do it?

To answer these questions, the ND-GAIN Global Adaptation Index of the University of Notre Dame's Environmental Initiative (France) can be used. It is a free and open source data. The index looks at two key dimensions. The first is "vulnerability" - a country's exposure, sensitivity and capacity to adapt to the negative effects of climate change. It considers six life-supporting sectors: food, water, health, ecosystem service, human habitat, and infrastructure. The second dimension is "readiness" - a country's ability to leverage investments and convert them to adaptation actions. It considers three components: economic, governance and social readiness (ND-GAIN Country Index).

As measured by the index, the top 10 most vulnerable countries in 2016 were Niger, Somalia, Chad, Micronesia, the Solomon Islands, Guinea-Bissau, Sudan, Liberia, Mali and Eritrea - all are developing countries with low GDP per capita in Africa and Asia. At the same time the top 10 least vulnerable countries were Switzerland, Norway, Luxemburg, Germany, Australia, Canada, France, UK, Sweden and Spain - all with a high GDP per capita, many of them are in Europe.

Again, top 10 countries least ready to adapt to climate change are low income countries of Africa and Asia with one exception: Somalia, Eritrea, Central African Republic, Chad, Democratic Republic of Congo, Democratic People's Republic of Korea, Libya, Zimbabwe, Venezuela and Haiti. Not surprisingly the top 10 countries most ready to adopt are high income countries: Singapore, New Zealand, Norway, Denmark, Finland, Sweden, Austria, Republic of Korea, Iceland and Switzerland - seven of them are European.

It draws attention to a major global problem as a World Bank's statement puts it: "Low income countries tend to be more vulnerable, and less equipped to invest against, extreme climate impacts". (World Bank Pubs 2018) Figure 1 below presents the position of the countries by their overall ability to withstand climate effects as measured by the ND-GAIN Country Index for 2016 combining vulnerability and readiness. The darker the country on the map is, the more resistant it is.

As far as Europe is concerned, the "Old Continent" is also affected by climate change although the situation in this respect is much more favourable in Europe than in Africa or Asia. Within Europe the most endangered territories are the sea coasts and some regions of Central Europe. The Scandinavian and some Western European countries are the most prepared to cope with climate change effects, while the Southern and Eastern part of the continent is less resistant. 
Figure 1. Resistance of Countries against Climate Effects as Measured by the NDGAIN Country Index (2016)

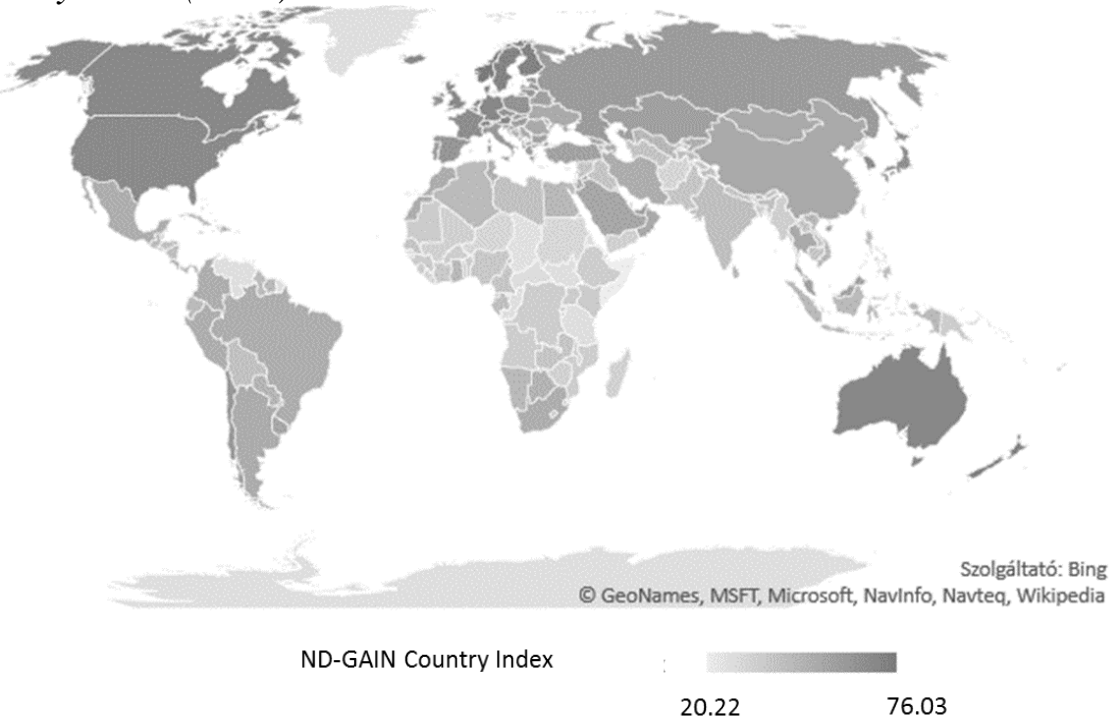

Source: Author's own map using data from ND Country Index, https://ntrda.me/2ATM9E4 [Accessed 19.11.2017].

During the past 15 years Europe made considerable efforts to improve resilience. 23 out of the 39 countries in Europe succeeded improving their overall ND-GAIN Country Index score from 2000 to 2016. Half of them belong to the group of high GDP per capita countries, one third of them to the upper middle and 3 countries to the lower middle GDP per capita group. The scores of the rest of the countries were either maintained or slightly declining but with less than one point on the scale.

Figure 2 below presents the ND-GAIN Country Index of the European countries in 2000 and 2016.

Figure 2. ND-GAIN Country Index of the European Countries in 2000 and 2016

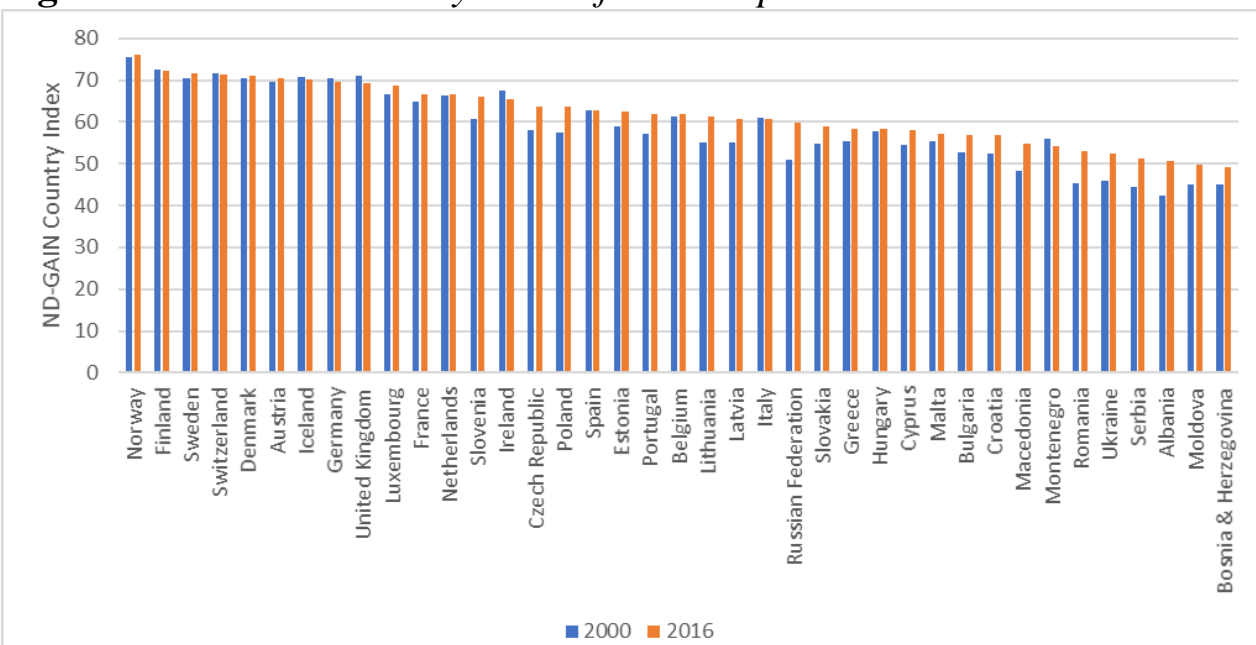

Source: Author's own chart using data from ND-GAIN Country Index https://ntrda.me/2QE7B9V [Accessed: 19.11.2017]. 


\section{The Root Cause: CO2 Emission}

As $\mathrm{CO} 2$ emission is considered the root-cause of climate change due to human activity on the Earth, which has increased considerably during the past twenty-five years and reached a level that endangers the climate. Figure 3 below shows the increase of the total $\mathrm{CO} 2$ emission by all countries of the world between 1990 and 2015 measured in kton.

Figure 3. Total CO2 Emission of all Countries 1990-2015 (kton)

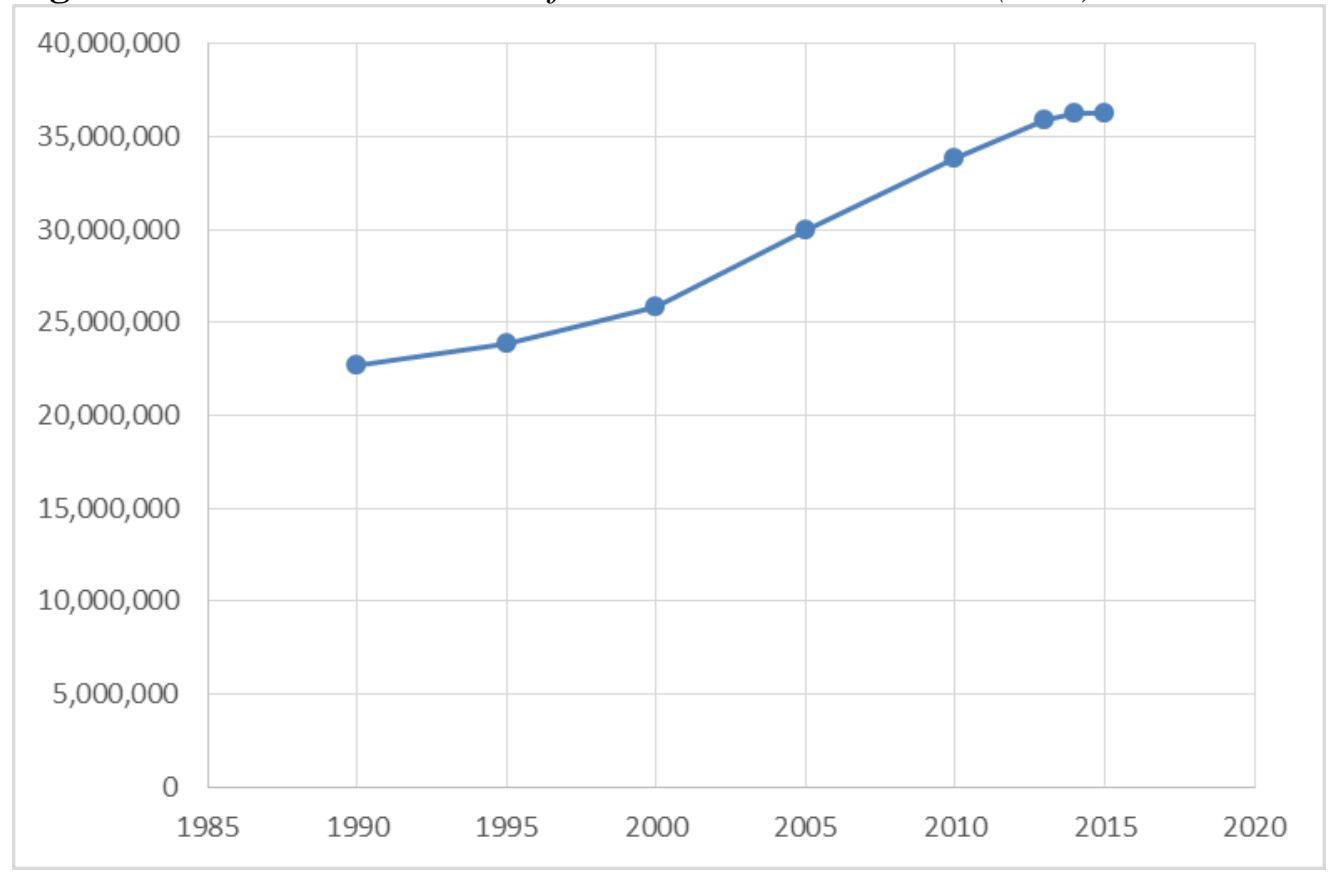

Source: Author's own chart using data from EDGAR (2017).

In 2015 the world produced over 35,633 million of tonnes of carbon dioxide, which means a sharp increase of nearly 60 percent between 1990 and 2015 . Emission is highly concentrated to the industrialized counties, as the top 20 emitters are accountable for 79 percent of it.

China is far more the largest emitter country producing 10,642 million of tons of $\mathrm{CO} 2$ with an enormous increase (354 percent) in the past twenty-five years representing 29 percent of the global $\mathrm{CO} 2$ emission. The USA is the second largest emitter with 5,114 million of tons but with "only" a 3 percent increase over the same period, representing $14 \%$ of the total emission. Other large emitter countries are India, Russia, Japan (all above 1,000 million of tons) with a share of 3-7 percent of the total emission. While there was a sharp increase in emission of CO2 in India (369 percent) and a moderate one in Japan (8 percent), emission by Russia decreased considerably during the past 25 years (29 percent). Table 1 below presents the top 20 global CO2 emitter countries and their emission in 2015, the increase of their emission from 1990 to 2015 and their share in the total emission of the world in 2015. 
Table 1. Top 20 Global CO2 Emitter Countries 1990-2015

\begin{tabular}{|l|c|c|c|c|}
\hline Country & $\mathbf{1 9 9 0}$ & $\mathbf{2 0 1 5}$ & $\begin{array}{c}\text { Increase } \\
\text { from 1990 to } \\
\mathbf{2 0 1 5}\end{array}$ & $\begin{array}{c}\text { Share in the } \\
\text { total } \\
\text { emission in } \\
\mathbf{2 0 1 5}\end{array}$ \\
\hline \hline Unit & kton CO2 & kton CO2 & $\mathbf{\%}$ & $\mathbf{\%}$ \\
\hline World Total & $22,452,432$ & $35,633,093$ & $159 \%$ & $100.0 \%$ \\
EU-28 & $4,334,975$ & $3,424,778$ & $79 \%$ & $9.6 \%$ \\
\hline China & $2,305,425$ & $10,461,742$ & $454 \%$ & $29.4 \%$ \\
USA & $4,955,641$ & $5,114,424$ & $103 \%$ & $14.4 \%$ \\
India & 655.462 & $2,419,637$ & $369 \%$ & $6.8 \%$ \\
Russia & $2,379,433$ & $1,698,007$ & $71 \%$ & $4.8 \%$ \\
Japan & $1,158,222$ & $1,254,800$ & $108 \%$ & $3.5 \%$ \\
Germany & $1,003,149$ & 765,923 & $76 \%$ & $2.1 \%$ \\
Canada & 554,684 & 682,765 & $123 \%$ & $1.9 \%$ \\
Iran & 201,720 & 628,611 & $312 \%$ & $1.8 \%$ \\
Korea & 268,057 & 601,322 & $224 \%$ & $1.7 \%$ \\
Saudi Arabia & 167,929 & 512,351 & $305 \%$ & $1.4 \%$ \\
Indonesia & 159,852 & 498,098 & $312 \%$ & $1.4 \%$ \\
Brazil & 215,804 & 492,986 & $228 \%$ & $1.4 \%$ \\
Mexico & 289,350 & 450,999 & $156 \%$ & $1.3 \%$ \\
Australia & 276,218 & 419,088 & $152 \%$ & $1.2 \%$ \\
United Kingdom & 575,834 & 392,946 & $68 \%$ & $1.1 \%$ \\
South Africa & 268,333 & 392,467 & $146 \%$ & $1.1 \%$ \\
Italy & 423,297 & 355,143 & $84 \%$ & $1.0 \%$ \\
Turkey & 149,477 & 349,756 & $234 \%$ & $1.0 \%$ \\
France & 376,700 & 324,691 & $86 \%$ & $0.9 \%$ \\
Poland & 358,700 & 288,938 & $81 \%$ & $0.8 \%$ \\
\hline Total of Top 20 countries & $16,743,287$ & $28,104,698$ & $168 \%$ & $78.9 \%$ \\
\hline Sourc: A & & &
\end{tabular}

Source: Author's own table using data from EDGAR (2017).

With regard to Europe, the EU-28 is the third largest emitter of the world with 3,424 million of tons of $\mathrm{CO} 2$ providing nearly 10 percent of the global emission. It is important to note, that contrary to China and the US, the EU-28 succeeded to cut emission by 21 percent between 1990 and 2015 - due not only to the economic crisis but to its considerable effort to "green the economy".

Within Europe, Germany is far more the largest CO2 emitter in the EU-28, followed by the United Kingdom, Italy, France, Poland and Spain. These large emitter countries of Europe succeeded to decrease emission by 14-32 percent between 1990 and 2015, except for Spain, where CO2 emission has increased by 15 percent during the same period. These six countries together, account for 70 percent of the total $\mathrm{CO} 2$ emission of the EU. Figure 4 below presents how $\mathrm{CO} 2$ emission has changed in the EU-28 member-states between 1990 and 2015. 
Figure 4. CO2 Emission by the Current Member-States of the European Union $1990-2015$

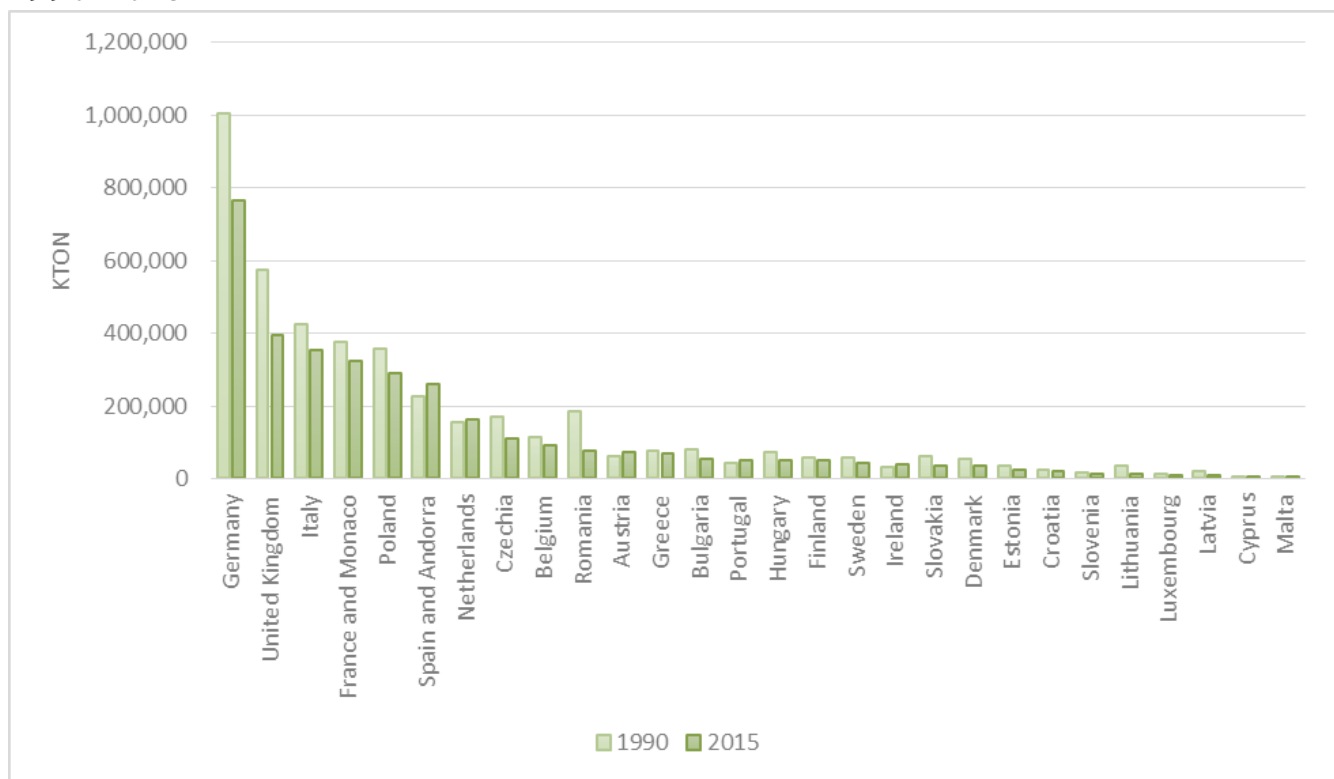

Source: Author's own chart using data from EDGAR (2017).

$\underline{\text { The Need for Climate Protection and its Directions }}$

Actions against climate change are called climate protection. By the 1980s it turned out that action against climate change is not possible at the level of individual countries, it requires global action. This led to the adoption of the United Nations Framework Convention on Climate Change (UNFCCC) adopted in 1992 at the Rio Earth Summit and to the Conference of Parties (COP) held each year. Based on the UNFCCC and after many rounds of negotiations the Paris Climate Agreement was signed in 2015, which is the most extensive international cooperation in the fight against climate change. "Combating Climate Change and its Effects" is also included in the UN "Sustainable Development Goals" adopted in 2015 (Goal 13: Climate Action, UN 2015).

The two main directions of climate protection are mitigation and adaptation. The UN International Panel on Climate Change (IPCC) defines climate mitigation as: "An anthropogenic intervention to reduce the sources or enhance the sinks of greenhouse gases." Climate adaptation refers to the ability of a system to adjust to climate change (including climate variability and extremes) to moderate potential damage, to take advantage of opportunities, or to cope with the consequences. The IPCC defines adaptation as the "adjustment in natural or human systems in response to actual or expected climatic stimuli or their effects, which moderates harm or exploits beneficial opportunities" (UN 1992). Of these two directions, mitigation is the dominant, adaptation gets still less attention. 


\section{$\underline{\text { Financing Climate Actions }}$}

The key question of climate protection is climate finance. Climate finance is part of the environmental finance and partly overlaps with green finance. It is a heavily contested term. From a climate justice perspective, it refers to the transfer of public resources from North to South to cover the costs of dealing with the long-term impacts of climate change. This money, a key component of climate debt, should also be provided to help Southern countries to pursue low-emissions paths without repeating the unsustainable reliance on fossil-fuels that was central to the industrialization of Northern countries. Other definitions are broader and refer to all financial flows relating to climate mitigation and adaptation (Reyes 2012). They include aid, private and equity investments, in case they are related to climate protection.

Estimated global total climate finance by 'Carbon Brief'- a UK-based website covering the latest developments in climate science, climate policy and energy policy - amounted to USD 340-650 billion in 2014. Developed countries transferred USD 40-175 billion to developing countries, out of which USD 35-50 billion was coming from public and USD 5-125 billion from private sources (Yeo 2015). Public climate finance is constantly increasing. From the annual USD 35 billion in 2011-12 it increased to USD 42 billion in 2013-14, and it will reach USD 67 billion by 2020 (ODI 2016). This is getting closer to the USD 100 billion pledge of the Paris Climate Agreement, but still there is a gap. More than half of this amount is bilateral financing, 40 percent is provided by MDBs, some percentage is financed through multilateral climate funds, part of which is managed also by MDBs, mainly by the World Bank.

The institutional structure of climate finance is rather complex and includes many actors (Nakhooda et al. 2015). Contributors are the developed donor countries, the European Union and some subnational organizations. They create dedicated climate finance funds and initiatives and establish bilateral and multilateral institutions, including MDBs. Bilateral institutions generally work with implementing agencies to execute their projects. Multilateral institutions use both market and non-market mechanisms to meet their climate goals. Market mechanisms - created by the Kyoto Protocol - are International Emissions Trading, Clean Development Mechanism and Joint Implementation. Non-market mechanisms is a broad basket, it can be anything provided it is not market-based, for instance cooperation on climate policy, fiscal measures, such as putting a price on carbon or applying taxes to discourage emissions. Recipients are the beneficiary developing countries. They usually work with regional and national implementing agencies and funds. Figure 5 below shows the model of institutional structure of climate finance. 
Figure 5. Model of Institutional Structure of Climate Finance

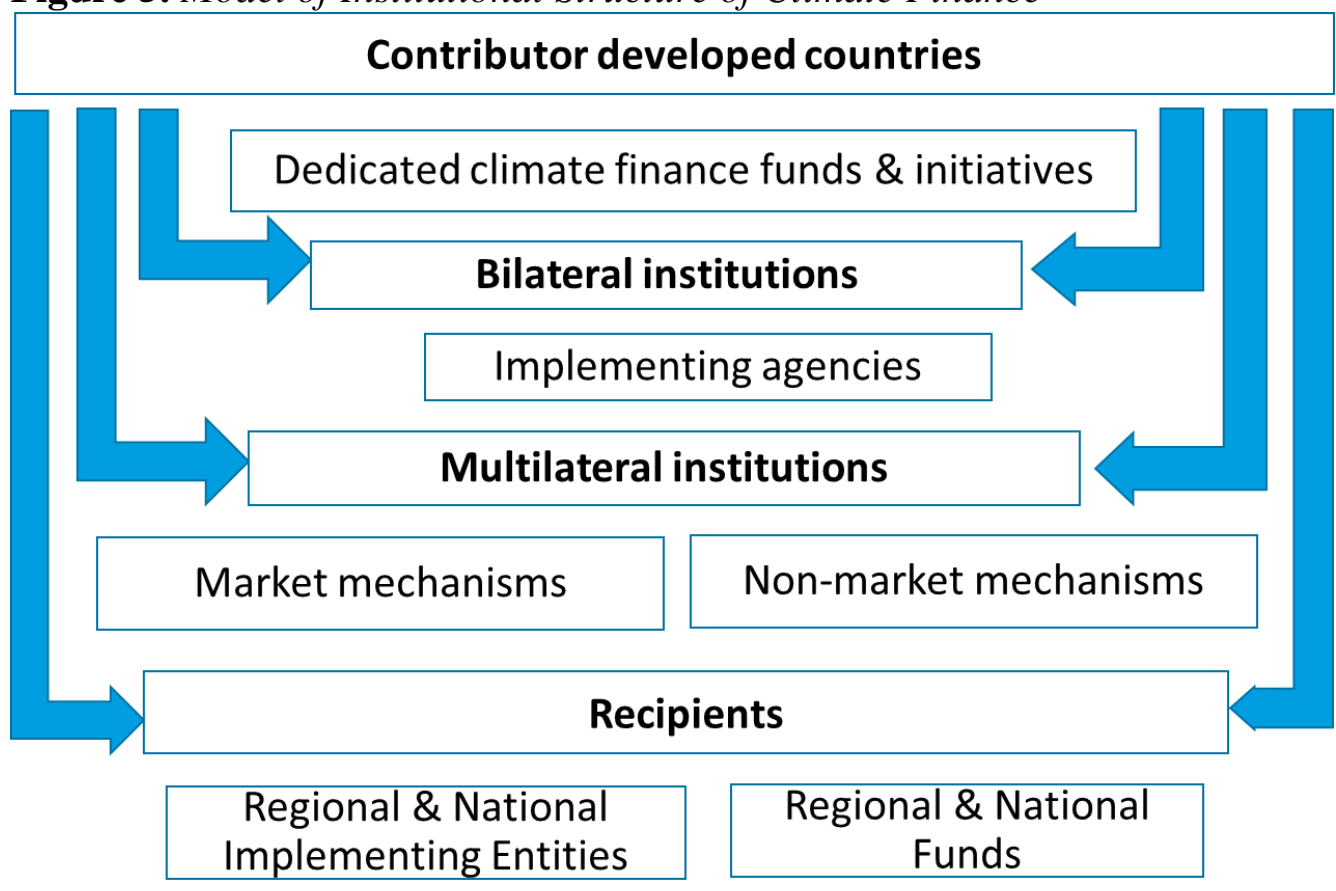

Source: Author's.

\section{The Role of Multilateral Development Banks in Climate Finance}

$\underline{\text { Multilateral Development Banks as Key International Financial Institutions }}$

Multilateral Development Banks (MDBs) are International Financial Institutions (IFIs). They are key members of the Bretton Woods financial system established after the World War II by sovereign states to foster reconstruction and development. They are important financial intermediators providing finance for long-term and risky investments which are not attractive enough for the private sector but badly needed for development, such as infrastructure, economic and social environment etc. They focus on the developing and the transition countries providing loans and guarantees, technical advice and make equity investments. They are owned by their shareholders and the decision-making is based on the shareholder's votes. This way the big donor countries can exercise heavy influence on the decisions which raises issues in the time of global power shift to a multipolar world and when recipient countries want to have a stronger voice (Babb 2009).

The largest and globally operating MDB is the World Bank (WB), which serves as a model for the regional development banks: the African (AfDB), Asian (ADB) and Inter-American Development Bank (IDB), the European Bank for Reconstruction and Development (EBRD) and the bank of the European Union, the European Investment Bank (EIB).

These institutions are only one group of the most important players in global climate finance and can satisfy only a part of the development needs. Their role is unique, they cooperate with other public and private finance institutions to 
mobilize as much resources as possible through the best use of opportunities and risk sharing. In addition, they are extremely important in the development and dissemination of norms (Park and Vetterlein 2010).

However, MDBs and their activities are also heavily criticized. On the one hand, the influence of the US in their governance and decision-making is said to be problematic, which is a consequence of their ownership structure. On the other hand, their caution and risk aversion make it difficult to finance projects of those who are in the greatest need. As MDBs are regularly rated by large international credit rating agencies, and their position on the capital markets is determined by their rating, they only provide loans to creditworthy borrowers and under strict conditions, which does not necessarily coincide with development needs. Criticism is also concerned with their bureaucracy, sluggishness and inflexibility, which makes it difficult and time-consuming to dynamically implement projects in the fast-paced world (Ben-Artzi 2016).

As MDBs are key international financial institutions, it is important to learn if they are committed to financing climate actions? Is climate finance a priority area in their strategy? What is the share of climate finance in their activities?

\section{$\underline{\text { Multilateral Development Banks' Commitment to Climate Finance }}$}

MDBs are active in climate finance. They set strategies and action plans for financing climate actions. They declared their commitment to the Paris Climate Agreement in 2015 and play an important role in delivering the annual USD 100 billion climate finance commitment of the developed countries.

Under the term climate finance, MDBs understand the use of financial resources for development activities devoted to mitigating and/or adapting climate change impacts in the developing and emerging countries. For accounting purposes, they have developed and use a common methodology based on the list of activities that can be linked to low carbon emissions (MDB Methodology 2015).

\section{Climate Change Strategies of the Multilateral Development Banks}

All MDBs have strategic documents guiding their activities in climate finance. These documents were elaborated during the past ten years, mainly following the Paris Climate Agreement signed in 2015.

The African Development Bank (AfDB) developed its "Strategy on Climate Risk Management and Adaptation" (CRMA) in 2009 (AfDB 2009). It calls for increased support for capacity building of African countries to tackle climate change risks. It also ensures that all investments financed by the Bank are "climate-proof", meaning that they are designed, installed, implemented and managed to reduce to a minimal level the adverse effects of climate change, with the most cost-effective ratio as possible. Based on this strategy a "Climate Change Action Plan" (CCAP) was prepared for the period of 2011-2015 as well (AfDB 2011). 
The Asian Development Bank (ADB) published its priorities for climate action in 2010 in a document titled "Addressing Climate Change in Asia and the Pacific: Priorities for Action". It aims at helping the region to be more resilient to the adverse impacts of climate change and follow a low-carbon path for economic growth and poverty reduction (ADB, 2010). In 2017 a "Climate Change Operational Framework" was developed for the period between 2017 and 2030 determining "Enhanced Actions for Low Greenhouse Gas Emissions and ClimateResilient Development" (ADB 2017).

The Inter-American Development Bank (IDB) issued its "Integrated Strategy for Climate Change Adaptation and Mitigation, and Sustainable and Renewable Energy" in 2011 (IDB 2011). Its objective was to contribute to low carbon development and address key vulnerabilities to the consequences of climate change in Latin-America.

The European Bank for Reconstruction and Development (EBRD) announced its overall "Green Economy Transition" (GET) approach in 2015. It states that with sustainable investments EBRD helps to mitigate and/or build resilience to the effects of climate change and other forms of environmental degradation (EBRD 2015). EBRD also introduced green economy aspects into the project evaluation criteria.

The European Investment Bank (EIB) adopted its "Climate Strategy" also in 2015, mobilising finance for the transition to a low-carbon and climate-resilient economy. It defines three strategic action areas: reinforcing the impact of EIB climate financing, increasing resilience to climate change, and further integrating climate change considerations across all EIB's standards, methods and processes. Within each of these areas operational initiatives are also launched (EIB 2015).

The World Bank Group (WBG)'s "Climate Change Action Plan 2016-2020" was published in 2016. It sets ambitious targets for 2020 in high-impact areas, including clean energy, green transport, climate-smart agriculture, and urban resilience, as well as in mobilizing the private sector to expand climate investments in developing countries and lays out concrete actions to help countries deliver on their contributions to global targets (World Bank, IFC, MIGA 2016).

These strategies demonstrate, that MDBs have elaborated climate finance strategy, developed action plans and are dedicated to follow up their climaterelated financing against their strategy.

\section{Financing Climate Actions by Multilateral Development Banks}

Financing climate actions has become an important direction in the activities of the MDBs. They spend over USD 35 billion annually on climate finance, 80 percent of which is for mitigation, and 20 percent for adaptation. Additionally, they provide approximately USD 50 billion co-financing per year with other international financiers and private investors. Between 2011 and 2017 their cumulative climate finance investment amounted nearly to USD 200 billion. The overwhelm-ming majority of climate finance ( 97 percent) is made from own, the rest is from external resources. They are provided by bilateral donors or the climate funds managed also by the MDBs. 
Loans represent 80 percent of climate finance of the MDBs. Aid, guarantees, budget support, capital investments and other assets have only 1-6 percent share but these are extremely important to mobilize the private sector for co-financing.

The focus areas of the climate actions are rather narrow. Most of the projects finance renewable energy and energy efficiency.

The main beneficiary of climate actions of the MDBs is the public sector of the recipient countries. Public sector accounts for two-third of climate finance from the MDBs' own sources, and three quarters of the external sources, being a much smaller amount. AfDB finances only the public sector, while EBRD provides more financing for the private than for the public sector.

Regarding geographical targeting, 20 percent of MDBs' climate finance is directed to non-EU Europe and Central Asia, 19 percent to South Asia, 15 percent to Latin America and the Caribbean, 14 percent to East Asia, 13 percent to $11 \mathrm{EU}$ countries, 9 percent to the Middle East and North Africa, and another 9 percent to the sub-Saharan region. Least developed countries receive 15 percent of climate finance and small island states another 2 percent. As climate finance is mainly used for mitigation, it is expected to bring the most benefit in the major polluting countries.

Climate finance represents 20-30 percent in the investment portfolio of MDBs in general. EBRD is the only exception, where the share of climate finance in the total investments is much higher, amounting to 38 percent (MDBs 2017).

Climate investments of the MDBs have fundamental impact on many people's lives. For example, "Renewable energy projects representing 10 gigawatts of generation capacity, and 10 new operations that when in place will improve the climate resilience of over 50 million people" - said John Roome, Senior Director for Climate Change of World Bank Group (WBG 2017). This way, MDBs are key to upscale climate protection in the region where they operate.

These figures show that MDBs have a prominent role in climate finance, which became even more important after the Paris Climate Agreement. Each MDB has set ambitious targets for rapidly expanding climate finance till 2020 and is enhancing its activity in this field. It is proven by the fact that they managed to increase the share of climate finance in their activity by 5-10 percent from 2016 to 2017. Table 2 below presents MDBs' climate finance commitment for 2020.

Nevertheless, critics are also voiced regarding the climate activities of the MDBs. Civil Society Organizations (CSOs), that have a global or regional reach closely watch these investments, report on their observations and act if needed. They managed to become a major stakeholder group with whom the MDBs are obliged to cooperate. Therefore, all MDBs have developed a platform to work with the CSOs, have regular consultations with them, invite them for their Annual Meetings, consider and react to their opinion, findings and actions. 
Table 2. MDBs' Commitment to Climate Finance

\begin{tabular}{|c|c|}
\hline & 2020 Climate Finance Target \\
\hline ADB & $\begin{array}{l}\text { To double climate finance to USD } 6 \text { billion per annum, USD } 4 \text { billion for } \\
\text { mitigation and USD } 2 \text { billion for adaptation (up from USD } 3 \text { billion in 2015) }\end{array}$ \\
\hline AfDB & $\begin{array}{l}\text { To triple climate finance to } 40 \text { percent of the annual investments, ca. USD } 5 \\
\text { billion (up from } 26 \text { percent on average between 2011-2014) }\end{array}$ \\
\hline EBRD & $\begin{array}{l}40 \text { percent of annual investments for green finance (composed of climate } \\
\text { finance and finance for projects with a possible environmental impact) (up } \\
\text { from } 25 \text { percent on average between 2010-2014) }\end{array}$ \\
\hline EIB & 35 percent of annual lending, ca. EUR 2 billion per year ( 25 percent in 2015 ) \\
\hline IDBG & $\begin{array}{l}\text { To double climate finance to } 30 \text { percent of approved loans, an average of } \\
\text { USD } 4 \text { billion a year, and climate risk assessment, identification of } \\
\text { opportunities and measures to improve resistance and mitigate the effects of } \\
\text { climate change (up from } 14 \text { percent on average between 2012-2014) }\end{array}$ \\
\hline WBG & $\begin{array}{l}\text { To increase the amount of climate finance by one third to USD } 16 \text { billion } \\
\text { annually, and its share in the annual commitment to } 28 \text { percent. WBG wants } \\
\text { to maintain the current level of co-financing, which would increase climate } \\
\text { finance by another USD } 13 \text { billion a year. The combined value of direct and } \\
\text { co-financing would thus reach USD } 29 \text { billion a year. (up from } 21 \text { percent in } \\
\text { 2015) }\end{array}$ \\
\hline
\end{tabular}

Source: Author's own table using information from MDBs (2015) and Cuntz et al. (2017).

For example, the Arab NGO Network for Development (ANND) is focusing on the involvement of EIB and EBRD in the Arab Region, one of the most affected areas by climate change according to the UN Intergovernmental Panel on Climate Change (IPCC). In its paper on climate change ANND shows, that in spite the share of climate finance is relatively high in the total investment of both EIB and EBRD (22 and 15 percent respectively in 2013), the Arab region benefits only with 2 percent of it, which is a very low share compared to other regions (ANND 2017).

Referring to an analysis done by the Bankwatch, ANND warns that many EIB projects benefit the European companies the most and not the local communities. Energy projects ensure oil to European counties rather that increase energy efficiency locally. ANND also criticizes that EIB does not consider carbon footprint of the projects to express the merit of the project and does not pay enough attention to $\mathrm{CO} 2$ emission.

ANND shows, that in the climate financing activities of EBRD the share of the Southern and Eastern Mediterranean region (SEMED), - where the Arab countries belong to - was as small as 0.7 percent only between 2006 and 2013 . Less than one quarter of the energy projects is financing renewable energy, the rest, - more than three quarters of the projects - are dedicated to fossil fuels using the argument of energy security and efficiency. Environmental categorization of the projects is also problematic. Miscategorization misleads when calculating with the environmental impact of the projects and turns the attention away from possible environmental degradation.

ANND gives some recommendations, too. EIB and EBRD should imply with the decarbonization target by 2050 and stop to support coal, observe environmental 
and social standards, ensure that the green economy concept is not merely a rhetoric, promote the transfer and dissemination of clean and environmentally sound technologies, finance energy efficiency and ensure that privatization related to water, energy, roads etc. consider these sectors as basic rights of people living in that region and projects should not prohibit people from enjoying their rights. ANND is not the only critical voice to be heard. Other CSOs express similar concerns in all geographies regarding climate actions of MDBs, too.

To further foster climate finance MDBs need to take seriously these critics and recommendations, enlarge the scope of their activities and improve efficiency. To enlarge the scope new MDBs can be established, sources for climate finance can be increased, private capital can be mobilized and co-financing can be done with the private sector, risk sharing facilities can be provided by partial credit guarantees, financial innovations can be introduced like green bonds, cat bonds, green credit lines, insurance products etc., environmental and social assessment can be included in all projects. Other ways to enlarge the scope can be raising awareness, sharing knowledge, building up capacity and knowhow in risk assessment, helping to create bankable and environmentally sustainable projects. To increase efficiency project design, management and coordination could be improved, technical and financial experts could be involved, multiple barriers should be tackled, initial interventions could be scaled up and expanded, specific interventions could be replicated in different locations, and scaling up and reproduction could be mixed. These tools and solutions can be combined and taylor-made for the specific needs, once the MDBs keep their promises to stay committed to help the developing and emerging countries to cope with the challenge of climate change.

\section{Results}

The results of the above analysis show, that

- Climate change has become a reality of today and is one of the top risk factors endangering the Earth. $\mathrm{CO} 2$ emission is the main cause of climate change. Industrialized developed countries are the major emitters.

- Climate change affects all countries, though to a different extent. The most affected countries are low income developing countries in Africa and Asia, accounting for only a small part of global emission. They need financial resources for climate mitigation and adaptation.

- Climate protection is in the interest of the whole world to ensure proper conditions for the survival of mankind. International agreements have been concluded and signed by nearly every country in the world defining targets, actions and measures.

- Climate protection requires long-term and risky investments. Developed countries invest in climate finance also through the MDBs. MDBs have strong commitment to climate mitigation and adaptation, set strategies, provide loans and assistance for the recipient developing and emerging 
countries. They can meet part of the climate finance needs only but make effort to increase their contribution.

- To best utilize the potential of the MDBs' for climate finance they should enlarge the scope of their activities, improve efficiency and instead of favouring the interest of the donor countries, their climate-related projects should serve the interest of the local communities and people at first.

\section{Discussion}

The fight against climate change is in the interest of the entire world. Its success or failure will influence international power relations of the future, and vice versa, international power relations today outline what is possible to achieve and how in the field of climate protection. This way climate finance shapes geopolitics and it is being shaped by geopolitics at the same time. Therefore, power relations, interest of the stake-holders, long-term effects of the projects as well as ethical questions of justice and inequalities could be further discussed. The debate on development versus growth cannot be avoided, either. As all these questions are far reaching and complex, an interdisciplinary approach would be essential.

\section{Conclusions}

Climate change has highlighted the need for climate protection including international agreements, voluntary commitments, and investments for mitigation and adaptation which requires tremendous additional financing. Multilateral Development Banks play an important role to provide considerable funding. They account for about 40 percent of the total climate finance, while climate finance represents about 25-35 percent in their investments. Their role is extremely important not only due to the financing they provide but because of the norms, standards and expectations they create and implement. They are committed to include climate finance into their priorities and increase climate investments. This way they are key to upscale climate protection in their region and globally and fight against climate change. To meet these stretching targets, MDBs need to enlarge the scope, increase efficiency as well as listen to and act on well-based critics.

However, three major questions are remaining. Firstly, how will the US quit from the Paris Climate Agreement influence climate finance of the MDBs as the US has a considerable influence on them? Secondly, how will Brexit affect climate finance of EBRD and EIB? Thirdly, what will these changes mean for climate finance globally? To answer these questions further research would be essential. 


\section{Acknowledgements}

The author expresses special thanks to the University of Pécs, Doctoral School of Earth Studies and The Pallas Athéne Foundations for the grant provided for the participation on the $5^{\text {th }}$ Annual International Conference on Social Sciences organized by ATINER (Athens, 30-31 July 2018).

\section{References}

ADB (2010) Addressing Climate Change in Asia and the Pacific: Priorities for Action. Retrieved from https://bit.ly/2Q6SPsE. [Accessed 10 June 2018].

ADB (2017) Climate Change Operational Framework 2017-2030. Retrieved from https:// bit.ly/2eI6bHj. [Accessed 10 June 2018].

AfDB (2009) Strategy on Climate Risk Management and Adaptation (CRMA). Retrieved from https://bit.ly/2BNqyil. [Accessed 10 June 2018].

AfDB (2011) Climate Change Action Plan 2011-2015 (CCAP). Retrieved from https:// bit. \#ly/2k6mf6j [Accessed 10 June 2018].

ANND (2017) Series of analysis on European Financial Institutions engagement in the Arab Region. Paper \#2, European Investment Bank and European Bank for Reconstruction and Development and Climate Change. Retrieved from https://bit.ly/2BNP Pst. [Accessed 01 September 2018].

Babb S (2009) Behind the development banks. Chicago: University of Chicago Press.

Ben-Artzi R (2016) Regional Development Banks in Comparison. Cambridge: Cambridge University Press.

Bowman M (2015) Banking on Climate Change: How Finance Actors and Transnational Regulatory Regimes are Responding. Kluwer Law International.

Climate Change (n.d.) In Cambridge Dictionary. Retrieved form https://bit.ly/2QwCahB [Accessed 20 June 2018].

Cuntz C, Afanador A, Klein N, Barrera F, Sharma R (2017) Connecting multilateral climate finance to mitigation projects, Mitigation Momentum. ECOFYS, 13.

Dessler A (2012) Modern Climate Change, 239. New York, USA: Cambridge University Press.

EBRD (2015) Green Economy Transition Approach. Retrieved from https://bit.ly/2RvSJ Yr. [Accessed 10 June 2018].

EDGAR (2017) Emissions Database for Global Atmosphere Research: Global Fossil CO2 Emissions from 1990 to 2016 (EDGARv4.3.2_FT2016 dataset). Retrieved from https://bit.ly/2jfhZCE. [Accessed 20 September 2018].

EIB (2015) Climate Strategy. Retrieved from https://bit.ly/1W7HYGi [Accessed 10 June 2018].

IDB (2011) Integrated Strategy for Climate Change Adaptation and Mitigation, and Sustainable and Renewable Energy, 2011. Retrieved from https://bit.ly/2EaS23A. [Accessed 10 June 2018].

Lomborg B (2015) Impact of Current Climate Proposals. Retrieved from https://bit.ly/2z ErLXq. [Accessed 06 May 2018].

Markandya A, Galarraga I, Dirk Rübbelke D (Eds) (2017) Climate Finance: Theory and Practice. World Scientific Series on the Economics of Climate Change: (2), World Scientific.

Maxton G, Randers J (2016) Reinventing Prosperity. Vancouver BC, Canada: Greystone Books Ltd., David Suzuki Institute. 
MDBs (2015) 2015 Joint Report on Multilateral Development Banks' Climate Finance. 7. Retrieved from https://bit.ly/2rhGxyM. [Accessed 20 May 2017].

MDBs (2016) 2016 Biennial Assessment and Overview of Climate Finance Flows. United Nations Framework Convention on Climate Change, 6. Retrieved from https://bit.ly/ 2BOFj4j. [Accessed 20 May 2017].

MDBs (2017) 2017 Joint Report on Multilateral Development Banks' Climate Finance. Retrieved from https://bit.ly/2KWGRfH [Accessed 20 June 2018].

MDB Methodology (2015) MDB Methodology for Tracking Climate Adaptation. 2015 Joint Report on Multilateral Development Banks' Climate Finance. 2016, 8-9. Retrieved from https://bit.ly/2DZUbOV [Accessed 20 May 2017].

Nakhooda S, Watson C, Schalatek L (2015) The Global Climate Finance Architecture. Overseas Development Institute, London, UK - Heinrich Böll Stiftung North America, Washington, US, 3. Retrieved from https://bit.ly/2KQeIXt [Accessed 10 June 2016].

ND-GAIN Country Index (n.d.) Retrieved from https://ntrda.me/2J1WErL. [Accessed 20 September 2017].

O’Brien R, Goetz AM, Scholte JA, Williams M (2000) Contesting Global Governance. Cambridge Studies in International Relations: 71, Cambridge University Press, Cambridge, United Kingdom, 260.

ODI (2016) 10 things to know about climate finance in 2016. Overseas Development Institute, London - Heinrich Böll Stiftung North America, Washington, 1. Retrieved from https://bit.ly/2fUfPtc. [Accessed 20 May 2017].

Park S, Vetterlein A (2010) Owning Development - Creating Policy Norms in the IMF and the World Bank, 287. Cambridge, New York: Cambridge University Press.

Prakash A (2016) Next Geopolitics: The Future of World Affairs (Technology) Volume One, 186.

Reyes O (2012) A Glossary of Climate Finance Terms. Institute for Policy Studies, 9. Washington, USA. Retrieved from https://bit.ly/2KQfq75. [Accessed 15 July 2016].

Stewart RB, Kingsbury B, Rudyk B (Eds) (2009) Climate Finance: Regulatory and Funding Strategies for Climate Change and Global Development, New York and London: New York University Press.

Tankönyvtár (2010) A klímaváltozás fogalma és értelmezése. [The definition and interpretation of climate change]. Retrieved from https://bit.ly/2E8hOpn [Accessed 18 June 2017].

UN (1992) United Nations Framework Convention on Climate Change (UNFCCC). United Nations, 7. Retrieved from https://bit.ly/1oNZ0PZ. [Accessed 15 May 2017].

UN (2015) Sustainable Development Goals. United Nations. Retrieved from https://bit.ly/ 1mZqbqP [Assessed 15 May 2017].

Washington H, Cook J (2011) Climate Change Denial: Heads in the Sand, 192. New York, USA: Earthscan from Routledge, Abingdon.

WBG (2017) WBG Press release: MDBs Increase 2016 Financing to Tackle Climate Challenge. Retrieved from https://bit.ly/2KOiBMo [Accessed 15 May 2018].

WEF (2016) The Global Risk Report 2016. Geneva: World Economic Forum. Retrieved from https://bit.ly/1RRzt37. [Accessed 20 May 2018].

WEF (2018) The Global Risk Report 2018, 6. Geneva: World Economic Forum. Retrieved from https://bit.ly/2DVJWLn. [Accessed 20 June 2018].

Wired (2018) What is Climate Change? The Definition, Causes and Effects. Retrieved from https://bit.ly/2uuksQk. [Accessed 20 June 2018].

World Bank, IFC, MIGA (2016) World Bank Group Climate Change Action Plan 20162020. Washington, DC: World Bank. Retrieved from https://bit.ly/2DWQc5y. [Accessed 10 June 2018]. 
World Bank Pubs (2018, 11 June) Low-income countries tend to be more vulnerable to, and less equipped to invest against extreme, climate impacts [Tweet]. Retrieved from https://bit.ly/2rgSh4R. [Accessed 10 September 2018].

Yeo S (2015) Climate finance: Funding a low-carbon global economy. Carbon Brief 16.07.2015. Retrieved from https://bit.ly/2PglipA [Accessed 10 June 2016]. 